\title{
Physical Modelling of Earthquake-induced Liquefaction on Uniform Soil Deposit and Earth Structures Settlement
}

\author{
Avantio Pramaditya ${ }^{1,2}$, Teuku Faisal Fathani ${ }^{1,2, *}$ \\ ${ }^{1}$ Department of Civil and Environmental Engineering, Universitas Gadjah Mada, Yogyakarta, INDONESIA \\ Jalan Grafika No 2 Yogyakarta \\ ${ }^{2}$ Centre of Excellence for Disaster Mitigation and Technological Innovation GAMA-InaTEK, Universitas Gadjah Mada, Yogyakarta, \\ INDONESIA \\ Jalan Grafika No 2 Yogyakarta \\ ${ }^{*}$ Corresponding authors: tfathani@ugm.ac.id
}

SUBMITTED 3 September 2020 REVISED 17 September 2020 ACCEPTED 25 September 2020

\begin{abstract}
Earthquake-induced liquefaction has been a complex and challenging topic in the field of geotechnical engineering due to its ability to cause catastrophic damage to the surrounding area. The manifestation of earthquake-induced liquefaction as observed from the effect of its past occurrence is damages on the ground and structures such as buildings, earth structures, and important lifelines structures. Liquefaction is caused by the loss of strength and stiffness of the cohesionless saturated soils due to the rapid dynamic loads from the earthquake. However, its complexity and uncertainty make the problems as one of the challenging problems in geotechnical engineering. One of the method to analyse the phenomena is through Physical modelling. Model subjected to the geotechnical centrifuge is required to analyse and observed the earthquake-induced liquefaction phenomena and this study aimed to understand the liquefaction phenomena, mechanism, and consequences through physical modelling by centrifuge and laboratory tests. This involved the physical modelling of the embankment which lies on a liquefiable foundation ground and subjection to earthquake motion of the 2011 Tohoku Earthquake retrieved from K-Net Mito stations. Moreover, geotechnical centrifuge test with $50 \mathrm{~g}$ of centrifugal acceleration was conducted to create the conditions of the actual field and the behaviour of the model related to acceleration, pore pressure, and displacement was observed using sensors. The liquefaction manifestation was observed in the model with the occurrence of lateral spreading, remnants of the sand boils, and deformation of the embankment. Furthermore, excess pore water pressure was rapidly developed and the pore pressure ratio $\left(r_{u}\right)$ higher than 1 was found to have indicated the occurrence of liquefaction while the embankment settle was estimated at $0.43 \mathrm{~m}$
\end{abstract}

KEYWORDS Excess Pore Water Pressure; Geotechnical Centrifuge Test; Liquefaction; Physical Modelling; Settlement.

(c) The Author(s) 2020. This article is distributed under a Creative Commons Attribution-ShareAlike 4.0 International license.

\section{INTRODUCTION}

The earthquake is known as one of the most disastrous phenomena causing devastating damage to the surrounding area and one of the aftermath events which is able to cause more damage is liquefaction. This is one of the most important and interesting topics in geotechnical engineering (Kramer, 1996) and the occurrence of the Niigata and the Alaska earthquakes in 1964 demonstrated its effects and importance. Several hundreds of buildings were reported to have sunk and tilted while more than $50 \%$ of the damaged shallow and piled foundation were classified as intermediate and heavy damage at the Niigata earthquake (Kishida, 1966). Meanwhile, spectacular mud spouts, subsidence, and numerous ground cracks were observed during the preliminary evaluation after the Alaska earthquake (Grantz, Plafker and Kachadoorian, 1964). These earthquake-induced liquefaction events triggered geotechnical engineers to specifically study and research the concept of liquefaction and the more recent notable occurrences include the Great Hanshin Earthquake of 1995 (Kitagawa and Hiraishi, 2004), the Canterbury Earthquake Sequence of 2010-2011 (Cubrinovski et al., 2010), (Yamada et al., 2011), 2011 Tohoku Earthquake (Towhata et al., 2014), and Palu earthquake of 2018 (Kiyota et al., 2020). 
Liquefaction occurs in saturated cohesionless loose sandy soils which are unable to maintain their strength and stiffness due to the dynamic loading caused by the earthquake. The rapid loading of earthquake motion during this process triggers the development of pore water pressure and this further reduces the effective stress (Towhata, 2008) based on the Equation (1).

\section{Effective stress $=$ Total Stress (weight of overburden soil) - pore water pressure}

The increase in excess pore water pressure (EPWP) generated due to the ground shaking could cause an upward flow which has the ability of leading to the liquefied condition of the ground which happens at effective stress of zero with the contact of the soil particles released as if they are floating in the water (Ishihara, 1985).

The damages caused by the liquefaction are generally a combination of one or more ground failure which consists of several forms such as sand boils, flow failures, lateral spreading, and settlements (Towhata, 2008). Moreover, the possible manifestation of liquefaction depends on several factors including the site conditions, earthquake characteristics, and structural properties. The three types of liquefaction manifestation which are often encountered and essential in practice have been identified by Idriss and Boulanger (2008) and they include loss of strength, lateral spreading, and settlement with their importance observed from the case histories. The study by Cubrinovski et al. (2012) showed the typical damage encountered in the residential foundation was differential settlement produced by the permanent tilt of the residential house. Furthermore, earth structures such as embankment, levee, and river dike were also subjected to liquefaction-induced damages and several cases focused on earth structures have been studied. Takada et al. (1996) researched the river levees and embankment during the Kobe Earthquake and found the damage to be concentrated on the soft alluvial sandy subsoils where a lot of river levees are located. Green et al. (2011) also analysed the performance of levees during the Darfield Earthquake in 2010-2011 and discovered several damages at the levee along the Waimakariri and Kaiapoi Rivers due to the liquefaction in the foundation ground.

The complexity and difficulties associated with analysing and assessing the liquefaction phenomenon have led several researchers to study the concept through laboratory tests using physical modelling and geotechnical centrifuge test (Sharp, Dobry and Abdoun, 2003, Elgamal et al., 1996, and Adalier, Elgamal and Martin, 1998). The use of centrifuge test makes it possible to recreate the actual field conditions of soil stress and strains in a scaled physical model (Ng, 2014) and numerous efforts have been made to improve the quality of the geotechnical centrifuge tests. For example, Hushmand et al., (1988) conducted a centrifuge test for liquefaction using a newly constructed laminar box which accommodates reduced friction between adjacent layers of the box and increases the degree of accuracy for the data measurements. Moreover, the Liquefaction Experiment and Analysis Project (LEAP) is an international collaborator project with the objective to provide a high-quality database of centrifuge test which is applicable in assessing and validating constitutive models and techniques for analysis and mitigation (Manzari et al., 2018). The results of the centrifuge tests conducted as a part of LEAP projects are presented by Kutter et al. (2020).

Physical modelling was conducted with centrifuge test in this study to model the behaviour of earthquake-induced liquefaction to the earth structure on a laboratory scale. The centrifuge test was used to achieve the stress and strain of the actual field conditions and its results are expected to be the representation of the actual field conditions. The model subjected to centrifuge test was observed and analysed to enhance the understanding of the liquefaction mechanism and its consequences. 


\section{METHODS}

\subsection{Model Preparation}

The embankment lying on liquefiable foundation ground was physically modelled and this process including the centrifugal test requires having controlled materials and conditions. Kutter et al. (2020) presented the model specification of the LEAP projects which shows the setup and modelling process are required to be conducted with caution to achieve reasonable results. Moreover, fabricated soils were used as the materials for foundation ground and embankment model due to their controlled properties while the foundation ground was constructed using Toyoura sand which is popularly known as Japanese test sand and studied by several researchers (Koseki, Yoshida and Sato, 2005; Tatsuoka et al., 1986; Cubrinovski, 2011). Previous studies showed the mechanical properties of Toyoura sand are similar in dry and saturated state. Furthermore, the embankment was made with DL Clay mixed with silicon oil. It is important to note that the DL is the abbreviation for driftless and DL Clay was made from kaolin and silica stone with an average particle size of 28 . The index properties of Toyoura sand and DL Clay are, however, presented in Table 1.

The configuration of the model is presented in Figure 1 and shown to be built on a rigid rectangular box made from steel with a transparent side to observe the model. The container has a length of $600 \mathrm{~mm}$, a width of 240 $\mathrm{mm}$, and a height of $400 \mathrm{~mm}$ while the foundation ground is $220 \mathrm{~mm}$ high. Moreover, the groundwater table was set at $10 \mathrm{~mm}$ below the surface ground while the crest of the embankment is $80 \mathrm{~mm}$ and has $40 \mathrm{~mm}$ height with a slope of 1:1.5. Three types of instrumentation were installed at the foundation ground while accelerometers were placed in the model with an increment of $30 \mathrm{~mm}$ and pore pressure transducer (PPT) installed between them. The free field used consists of PPT 3, PPT 7, and PPT 11 while PPT 4, PPT 8, and PPT 12 were placed beneath the tip of the crest area. Furthermore, the centre of the embankment was monitored by PPT 5, PPT 9, and PPT 13 while PPT 6, PPT 10, and PPT 14 were beneath the toe of the embankment. Meanwhile, a linear variable displacement transducer was attached to the tip of the crest and the centre of the embankment. It is important to note that all the dimension mentioned were on the model scale with the details of the model test shown in Table 2.

Table 1 Index properties of Toyoura sand and DL Clay

\begin{tabular}{ll}
\hline Toyoura sand & \\
\hline Density, $\rho_{s}\left(\mathrm{~g} / \mathrm{cm}^{3}\right)$ & 2.65 \\
Mean particle size, $D_{50}(\mathrm{~mm})$ & 0.19 \\
Particle size, $D_{10}(\mathrm{~mm})$ & 0.14 \\
Maximum void ratio, $e_{\max }$ & 0.973 \\
Minimum void ratio, $e_{\min }$ & 0.609 \\
\hline DL Clay & \\
\hline Specific gravity $\left(G_{s}\right)$ & 2.65 \\
Liquid Limit, LL $(\%)$ & $\mathrm{NP}$ \\
Plastic Limit, PL $(\%)$ & $\mathrm{NP}$ \\
Plasticity Index, IP & $\mathrm{NP}$ \\
Coefficient of Permeability $(\mathrm{m} / \mathrm{s})$ & $9.0 \times 10^{-8}$ \\
\hline
\end{tabular}

Table 2 Details of the model test

\begin{tabular}{lll}
\hline \multirow{3}{*}{ Materials } & Foundation ground & Embankment \\
\cline { 2 - 3 } & $\begin{array}{l}\text { Toyoura sand, relative density }(D r) \text { of } \\
50 \%\end{array}$ & $\begin{array}{l}\text { DL Clay mixed with silicon oil; } \\
\text { slope of 1:1.5 }\end{array}$ \\
\hline Groundwater table & $0.5 \mathrm{~m}$ & 3 points \\
Accelerometers & 9 points & - \\
Pore pressure & 13 points & 3 points \\
Displacement transducer & - & \\
\hline
\end{tabular}




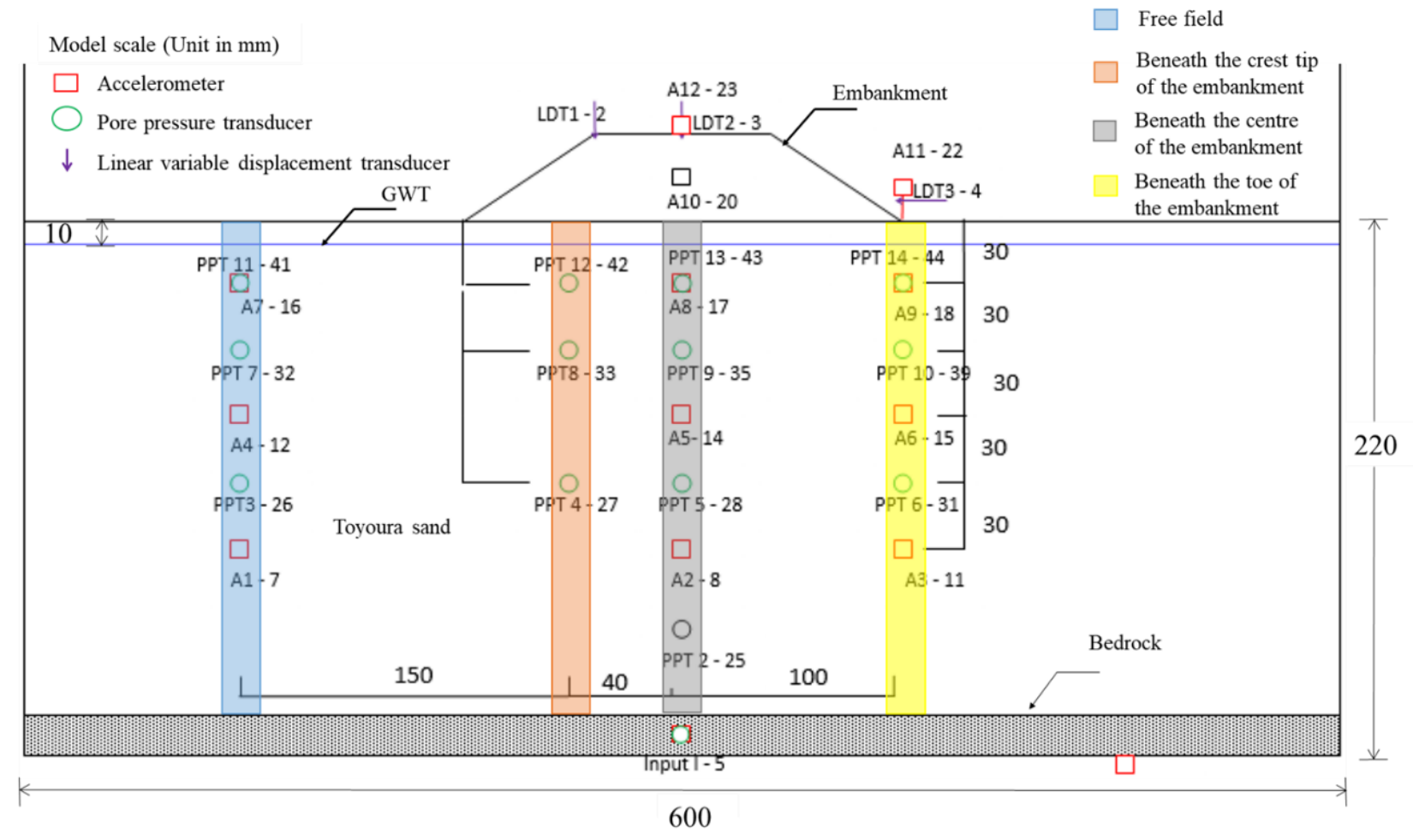

Figure 1 Model configuration.

The liquefiable foundation ground was prepared to have a relative density ( $D r$ ) of $50 \%$ based on the previous studies conducted by Maharjan and Takahashi (2014) and the preparation was similar to previous centrifuge tests (Adamidis and Madabhushi, 2018; Kutter et al., 2020; Maharjan and Takahashi, 2014). Moreover, the air pluviation method was used to achieve the desired relative density (Tabaroei et al., 2017) while the sand was poured using a hopper from above the container and conducted evenly in a back and forth manner. The desired density was obtained by keeping the falling height of the sand calibrated before the model preparation to be constant. Furthermore, the embankment was made manually by shaping the mixture of DL Clay with silicon oil at a ratio of $1: 2$ to ensure easy shaping which was directly implemented on the container after the preparation of the foundation ground.

\subsection{Centrifuge Test}

Centrifuge test has the ability to recreate the actual soil conditions into the scaled laboratory test model and this makes it possible to tackle and solve complex geotechnical problems through a laboratory test. Therefore, this method has been generally used to assess and validate the mechanism and behaviour of the soil (Youd, 1995) and also for the validation of constitutive models (Manzari et al., 2015). Moreover, the scaled model, $1 / \mathrm{N}$, is subjected to centrifugal acceleration, N.g, to accommodate the differences in confining pressures in order to replicate the actual stress and strains (Gopal Madabhushi, 2007). Meanwhile, the scaling law for the geotechnical centrifuge test presented by Schofield (1981) is shown in Table 3.

Table 3 Scaling law for geotechnical centrifuge test (after Schofield, 1981)

\begin{tabular}{lll}
\hline & Parameter & Scaling law \\
\hline General & Length $(\mathrm{m})$ & $1 / \mathrm{N}$ \\
& Area $\left(\mathrm{m}^{2}\right)$ & $1 / \mathrm{N}^{2}$ \\
& Mass & $1 / \mathrm{N}^{3}$ \\
& Volume $\left(\mathrm{m}^{3}\right)$ & $1 / \mathrm{N}^{3}$ \\
& Stress & 1 \\
& Strain & 1 \\
& Time & $1 / \mathrm{N}^{2}$ \\
Dynamic & (consolidation) & 1 \\
condition & Velocity & $\mathrm{N}$ \\
& Acceleration & $\mathrm{N}$ \\
& Frequency & $1 / \mathrm{N}$ \\
& Displacement & $1 / \mathrm{N}$ \\
\hline
\end{tabular}


The centrifuge test was conducted in this study using the Tokyo Tech Mark III centrifuge machine from the Department of Civil Engineering, Tokyo Institute of Technology with the schematic design presented in Figure 2. The model was placed at the swinging basket while counterweight was placed at the other side to stabilise the two centrifuge arms. Meanwhile, there are two electrical slip rings, one for recording the instrumentation data and the other one is for operation while $50 \mathrm{~g}$ of the centrifugal acceleration was applied to the model.

The load recorded in the 2011 Tohoku earthquake was used in the centrifuge test and the consequences of liquefaction were found in levees along Naka river in Mito City (Towhata et al., 2013) and the NS component of input motion retrieved was used from $\mathrm{K}-\mathrm{Net}$ stations located at Mito. It is important to note that the K-Net or Kyoshin-Network which is managed by National Research Institute for Earth Science and Disaster Resilience (NIED) is a comprehensive strongmotion seismograph network with approximately $20 \mathrm{~km}$ interval between the stations (Suzuki et al., 2017). The network is freely accessible to the public and the input motion used in this study is indicated in Figure 3. Meanwhile, the magnitude of the bedrock motion was assumed to be $70 \%$ of the surface motion while the maximum acceleration of the input motion was $0.29 \mathrm{~g}$.

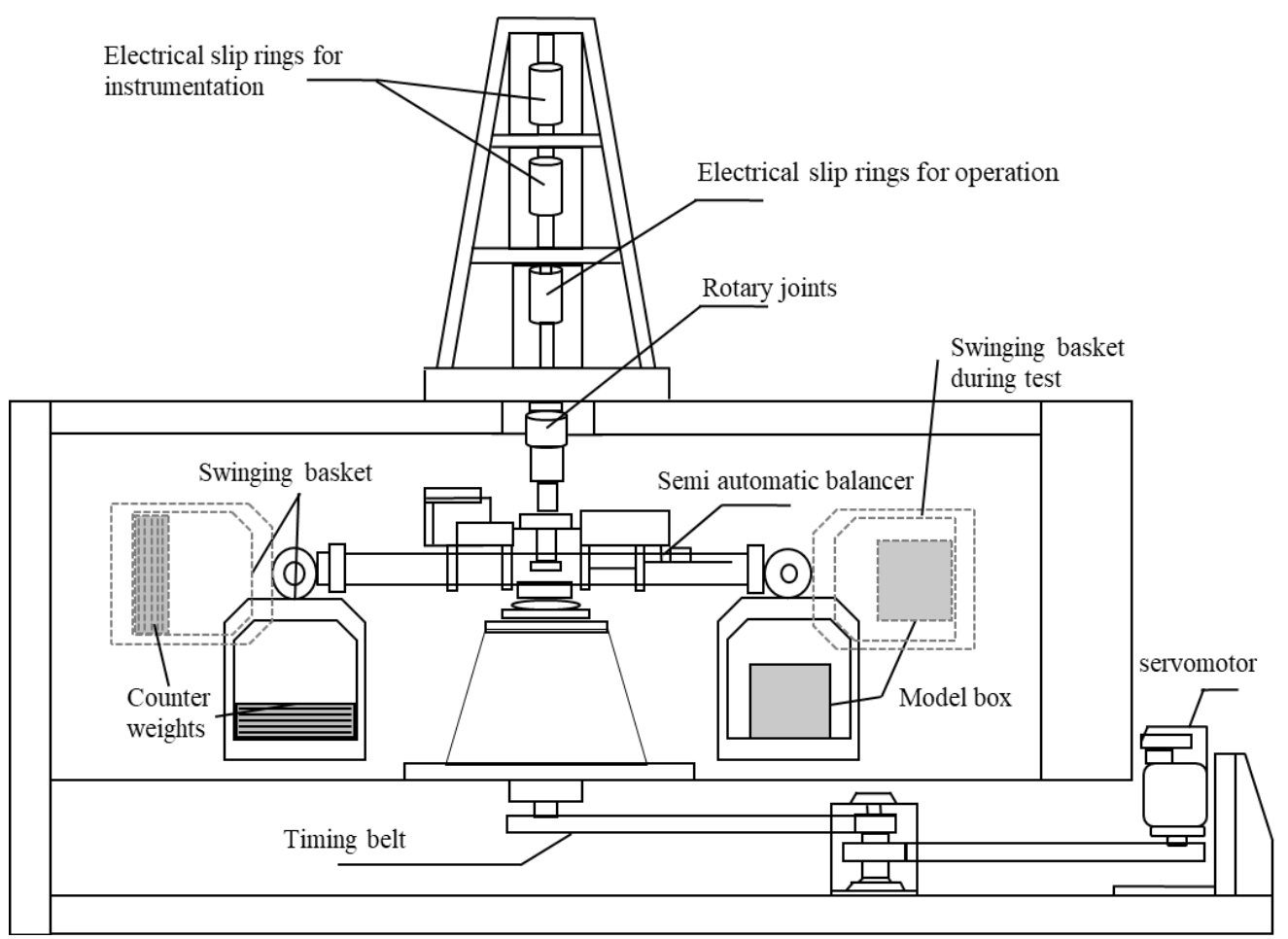

Figure 2 Tokyo tech Mark III sectional view illustration.

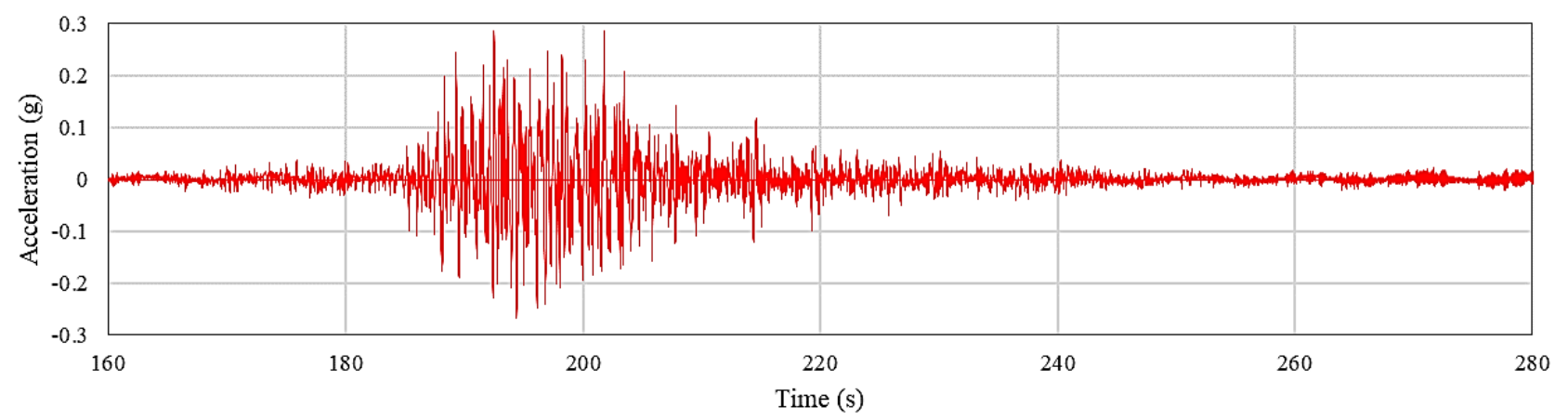

Figure 3 Input motion of the 2011 Tohoku earthquake used in this study. 


\section{RESULTS}

\subsection{Visual Assessment}

Figure 4 (a) shows the side view and (b) shows the top view of the model conditions after the centrifuge test. The black dash line is the initial shape of the embankment while the red dash line is the initial contour line. The embankment was observed in the figure to have undergone a settlement deformation partially due to the lateral spreading at the foundation ground as indicated by the bends of the contour line beneath the embankment towards the free-field area with a yellow marker in Figure 4 (a). Moreover, the foundation ground beneath the embankment sank slightly as shown in the foundation ground upheaval near the toe of the embankment as indicated with yellow circles. In Figure 4 (b), cracks were found at the top of the embankment while the remnants of the sand boils were at the foundation surface near the embankment. Furthermore, the fine-grained at the surface was able to contribute to the sand boils occurrence as observed in by Scott and Zuckerman (1972).

\subsection{Excess Pore Water Pressure}

Excess pore water pressure (EPWP) was obtained from the installed PPT at the foundation ground and this evident from the PPT installed in 4 different areas including the free field foundation ground, beneath the tip of the embankment crest, beneath the centre of the embankment, and beneath the toe of the embankment as shown in Figure 1. Meanwhile, the EPWP configurations made it possible to observe the effect of embankment on its generation as shown in Figure 5 in comparison with the free field.

Figure 5 (a) shows the EPWP generated at $1.5 \mathrm{~m}$ depth of the model and the EPWP was observed to have started to develop at approximately 187 $\mathrm{s}$ for all the locations, rapidly increased to $18 \mathrm{kPa}$ and steadily after reaching its maximum value. Meanwhile, the EPWP from beneath the crest and centre of the embankment slightly dissipated before it was increased to the same value with the other location. Figure 5 (a), therefore, shows there was no liquefaction as the EPWP generated was lower than the pore pressure ratio, $r_{u}=1$.

Figure 5(b) shows the EPWP generated at $3 \mathrm{~m}$ depth and the EPWP was developed up to approximately $30 \mathrm{kPa}$ and this also grew steadily except for the location beneath the toe of the embankment which was estimated to be up to 65 $\mathrm{kPa}$. This condition was not found at the $1.5 \mathrm{~m}$ depth but also discovered beneath the crest tip and centre of the embankment which has similar EPWP development as the location at the $1.5 \mathrm{~m}$ depth. Therefore, Figure 5 (b) shows that liquefaction occurred as the EPWP generated was close to the pore pressure ratio, $r_{u}=1$.
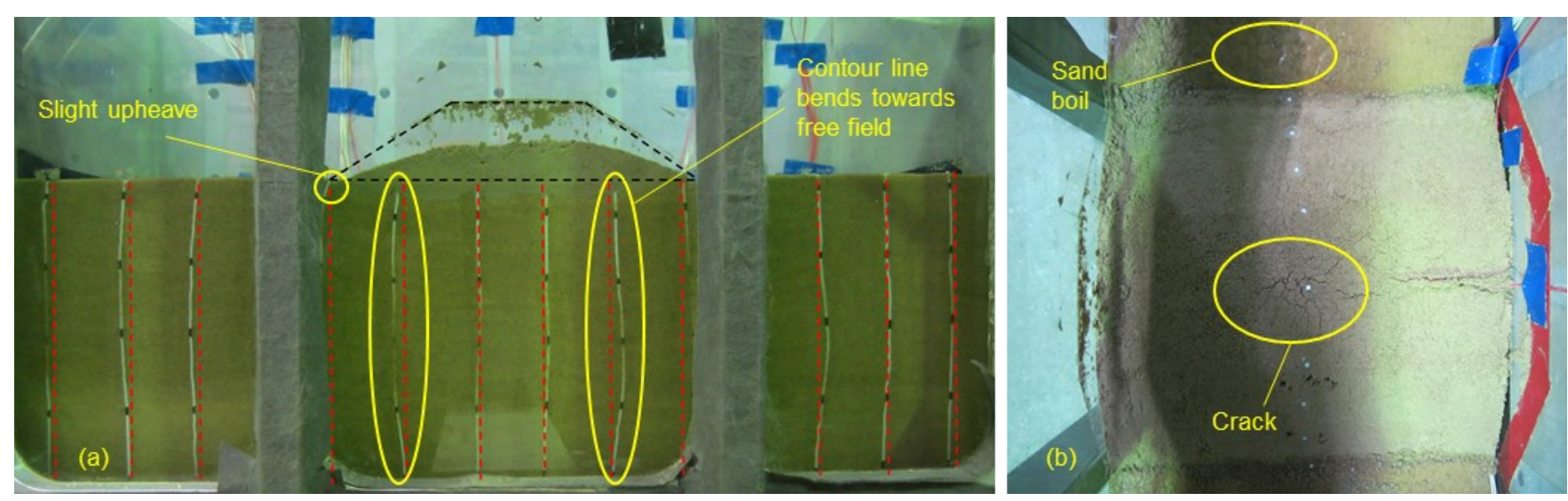

Figure 4 Model condition after subjected to the centrifuge test; (a) Side view; (b) Top view 
Figure 5 (c) shows the development of EPWP at 6 $m$ depth and the transducers placed beneath the tip of the crest was observed not to record any value for EPWP development. Meanwhile, the EPWP generated at other locations has a similar value up to approximately $55 \mathrm{kPa}$. Figure 5 (c) shows the occurrence of liquefaction due to the fact that the EPWP generated exceeded the pore pressure ratio, $r_{u}=1$.
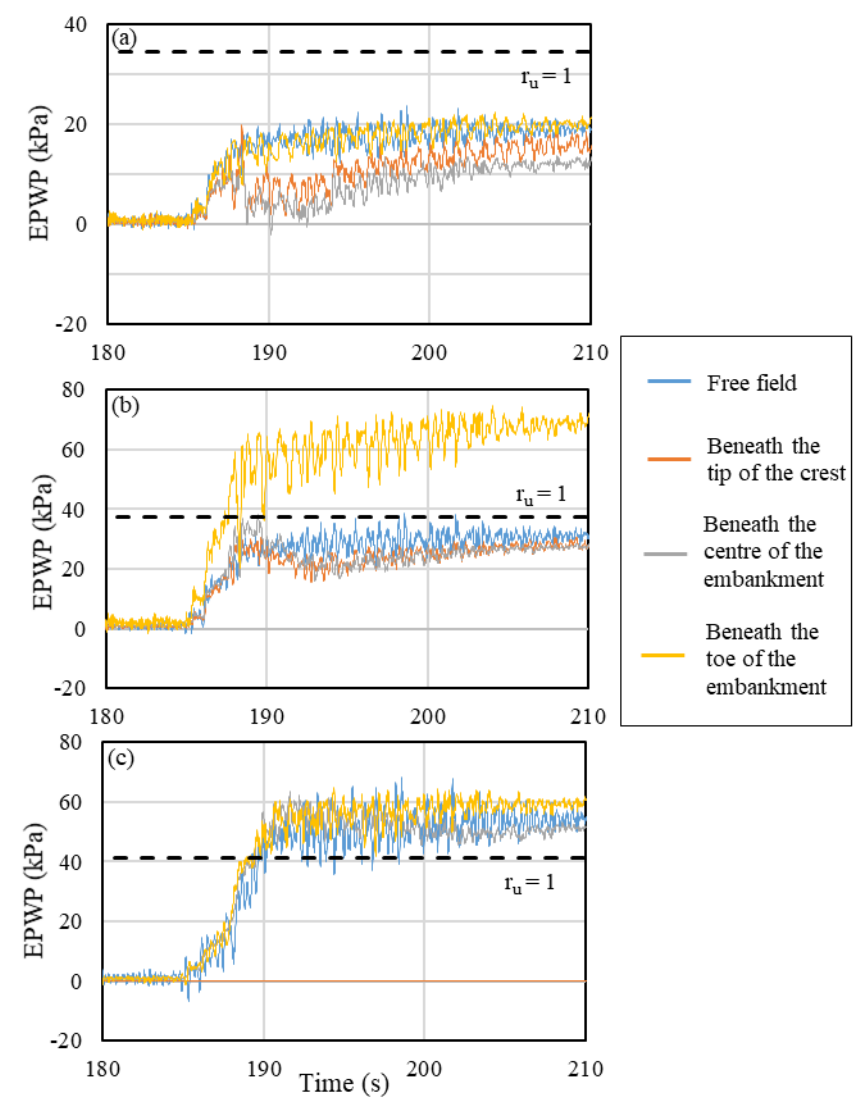

Figure 5 Excess pore water pressure generated at (a) $1.5 \mathrm{~m}$ depth, (b) $3 \mathrm{~m}$ depth, and (c) $6 \mathrm{~m}$ depth.

\subsection{Settlement}

The settlement of the embankment was obtained from the LVDT placed at the centre and tip of the crest and Figure 6 shows a significant amount of settlement occurred in a short period when the earthquake loading increased rapidly. The embankment started to deform at approximately $180 \mathrm{~s}$ and reached the maximum value before moving into the steady-state condition and this indicated a minimal settlement after the shaking. Moreover, there was no significant difference between the settlement found on the tip and the centre of the crest and this is in line with the findings of Rapti et al. (2018) that the depth of the liquefiable layer is very important to the determination of the seismic response of the embankment. There was, however, no significant response on the embankment when the liquefiable layer was located at the deep layer.

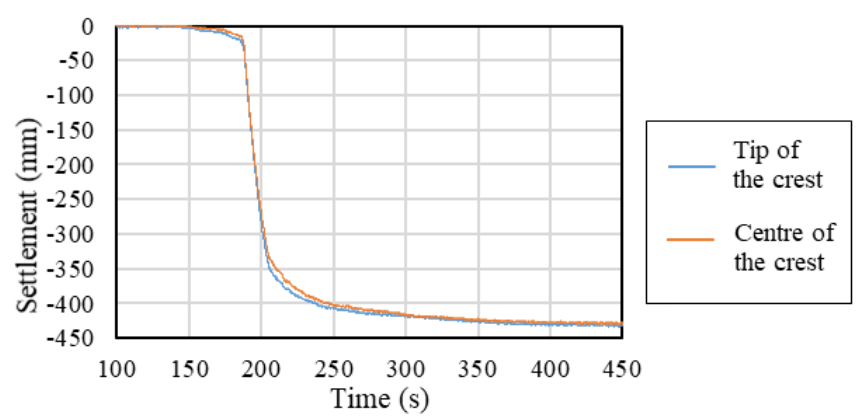

Figure 6 settlement at the tip and the centre of the crest of the embankment

\section{DISCUSSION}

The consequences of liquefaction on the foundation ground and earth structures were observed from the centrifuge test conducted on the physical model of embankment placed on the liquefiable ground. The visual assessment showed several liquefaction manifestations on both the foundation ground and embankment while the signs of lateral spreading and deformation of foundation ground as well as the settlement of the embankment were also presented. This phenomenon is in line with findings from several previous case histories such as Oka et al. (2012) which showed the typical damage patterns of earth embankment to be lateral expansion, settlement, sand boils, and cracks. Sasaki et al. (2012) also found that the levee along Tone River in Japan undergone $1 \mathrm{~m}$ of subsidence while crack was observed at the crest of the levee and significant distortion at the Hinuma levee. Similar damage patterns were also recorded in the 1988 Armenia earthquake (Yegian et al., 1994).

A sudden increase was observed in the EPWP at every location of the foundation ground as shown in Figure 7. The highlighted area indicates the EPWP started to increase during the rapid dynamic loads of the earthquake with the maximum value obtained at the highest peak 
ground acceleration. Moreover, the free field area and foundation ground beneath the embankment were generally observed to generate a similar response in terms of EPWP while the $3 \mathrm{~m}$ depth beneath the toe of the embankment developed up to $65 \mathrm{kPa}$ and this was much higher compared to the other locations with the same depth. It was also discovered to have different behaviour in comparison with others in the same location but at different depth and this was possibly associated with an error in data recording at the location. The ideal theory of liquefaction occurrence is when pore pressure ratio $r_{u}$ is 1 but the strain-controlled undrained cyclic simple shear test conducted by Hazirbaba and Rathje (2004) assumed any value greater than 0.9 . The results, however, showed liquefaction occurred at $6 \mathrm{~m}$ and $3 \mathrm{~m}$ depths of the free field as well as the $6 \mathrm{~m}$ depth of the foundation ground beneath the embankment while none was observed at the shallow part of the foundation ground. This was observed to be in line with the findings of Adalier et al. (1998) and Maharjan and Takahashi (2014) which reported a stiffer response beneath the embankment but the shallower part of the free field area also experienced liquefaction.

Different dissipation rate and process were observed at every location in relation to the EPWP with those at $6 \mathrm{~m}$ depth found to have dissipated quickly starting from approximately $255 \mathrm{~s}, 3 \mathrm{~m}$ depth was estimated to have started at $310 \mathrm{~s}$ while $1.5 \mathrm{~m}$ took the longest with approximately $340 \mathrm{~s}$. The dissipation rate and time are, however, governed by two main factors which are the duration of the seismic and drainage conditions (Day, 2002). The drainage conditions of the foundation ground were assumed to be the reason for the differences in dissipation time considering the fact that the same input motion was applied to the model. Meanwhile, the shallowest depth at $1.5 \mathrm{~m}$ was confined by the embankment constructed using clay materials and this led to longer dissipation process observed in comparison with deeper depth which has liquefiable soil on the upper and lower layers. Maharjan and Takahashi (2014) conducted a centrifuge test for models with uniform and non-uniform soil deposit and the results show the uniform deposits dissipated faster than the non-uniform deposits.
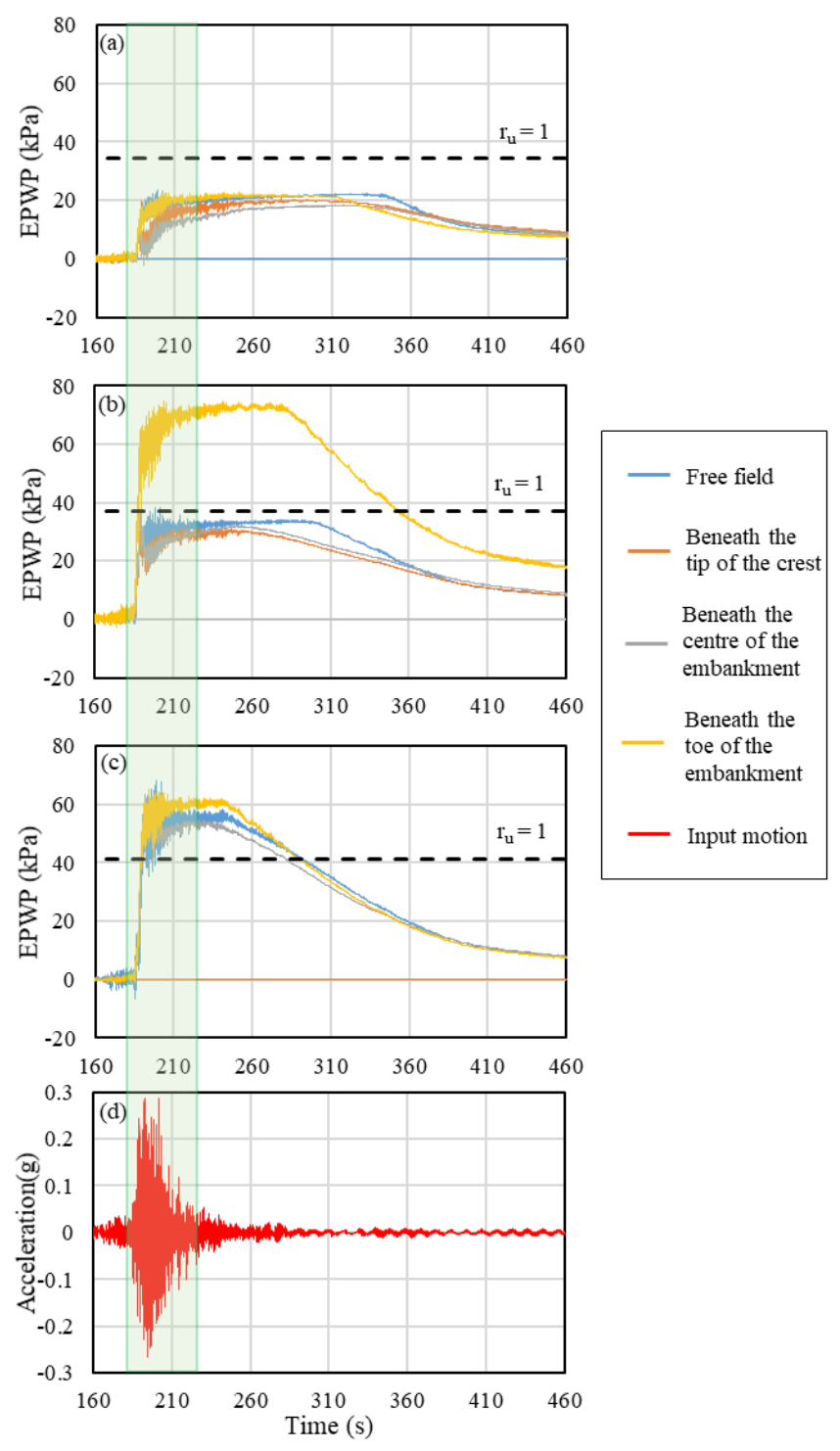

Figure 7 Time histories of excess pore water pressure from (a) $1.5 \mathrm{~m}$ depth, (b) $3 \mathrm{~m}$ depth, and (c) $6 \mathrm{~m}$ depth, and (d) input motion.

The settlement observed at the tip of the crest and the centre of the embankment was $0.43 \mathrm{~m}$. and $0.42 \mathrm{~m}$, respectively. The slightly smaller value observed at the centre indicates the deformation in shape was at the minimum while the settlement of the embankment was due to the liquefied foundation ground. Adalier et al. (1998) and Elgamal et al. (2002) observed similar conditions with the settlement found to be occurring at a nearly uniform rate and was due to the lateral spreading of the foundation ground 
while the additional settlement observed after the shaking was reported to be minimal.

\section{CONCLUSION}

An embankment model was placed on the liquefiable uniform ground deposits and subjected to the centrifuge test at $50 \mathrm{~g}$ of gravitational acceleration to replicate the actual stress and strains conditions on a laboratory scale through physical modelling. The behaviour of the model was observed and analysed and the visual assessment of its conditions after the centrifuge test showed the signs of liquefaction on the foundation ground to include lateral spreading, stretching of the embankment, settlement, and cracks at the top of the embankment. Moreover, the remnants of sand boils were also observed on the ground surface with the liquefaction found to have occurred on the free field at $6 \mathrm{~m}$ and $3 \mathrm{~m}$ depths as well as 6 $m$ depth for the foundation ground beneath the embankment which was indicated by the development of excess pore water pressure which exceeds the acceptable ratio, $r_{u}$, of 1 . A similar amount of settlement was recorded at the centre and tip of the crest while $0.43 \mathrm{~m}$ was recorded at the tip of the crest and 0.42 at the centre of the embankment. Therefore, the cause of the settlement was found to be partially due to the lateral spreading of the foundation ground and the settlement observed after the shaking was minimal.

\section{DISCLAIMER}

The authors declare no conflict of interest.

\section{ACKNOWLEDGMENTS}

This study was supported by JASSO under YSEP Program of the Tokyo Institute of Technology, Japan. The authors appreciate Prof. Akihiro Takahashi of the School of Environment and Society,

Department of Civil and Environment Engineering, Tokyo Institute of Technology for the guidance and facilities supplied to conduct this study. The authors also show gratitude to Sakae Seki, the laboratory technician at Soil Mechanics and Geotechnical laboratories for the support provided during the laboratory testing process.

\section{REFERENCES}

Adalier, K., Elgamal, A.W. and Martin, G.R., 1998. Foundation liquefaction countermeasures for earth embankments. Journal of Geotechnical and Geoenvironmental Engineering, 124(6), pp.500-517.

Adamidis, O. and Madabhushi, S.P.G., 2018. Experimental investigation of drainage during earthquake-induced liquefaction. Geotechnique, 68(8), pp.655-665.

Cubrinovski, M., 2011. Seismic Effective Stress Analysis: Modelling and Application. In: 5th International Conference on Earthquake Geotechnical Engineering. Santiago, Chile.

Cubrinovski, M., Green, R.A., Allen, J., Ashford, S., Bowman, E., Brendon, Bradley, Cox, B., Hutchinson, T., Kavazanjian, E., Orense, R., Pender, M., Quigley, M. and Wotherspoon, L., 2010. Geotechnical reconnaissance of the 2010 Darfield (Canterbury) earthquake. Bulletin of the New Zealand Society for Earthquake Engineering, 43(4), pp.243-320.

Cubrinovski, M., Henderson, D. and Bradley, B., 2012. Liquefaction Impacts in Residential Areas in the 2010-2011 Christchurch Earthquakes. Proceedings of the International Symposium on Engineering Lessons Learned from the 2011 Great East Japan Earthquake, pp.811-824.

Day, R., 2002. Geotechnical Earthquake Engineering Handbook. McGraw-Hill.

Elgamal, A., Parra, E., Yang, Z. and Adalier, K., 2002. Numerical analysis of embankment foundation liquefaction countermeasures. Journal of Earthquake Engineering, 6(4), pp.447471.

Elgamal, A., Zeghal, M., Taboada, V. and Dobry, R., 1996. Analysis of Site Liquefaction and Lateral Spreading Using Centrifuge Testing Records. Soils and Foundations, 36(2), pp.111121. 
Gopal Madabhushi, S.P., 2007. Ground improvement methods for liquefaction remediation. Proceedings of the Institution of Civil Engineers - Ground Improvement, 11(4), pp.195206.

Grantz, A., Plafker, G. and Kachadoorian, R., 1964. Alaska's Good Friday earthquake, March 27, 1964: A Preliminary Geologic Evaluation. U.S. Geological Survey Professional Paper, pp.1-35.

Green, R.A., Allen, J., Wotherspoon, L., Cubrinovski, M., Bradley, B., Bradshaw, A., Cox, B. and Algie, T., 2011. Performance of Levees (Stopbanks) during the 4 september $2010 \mathrm{Mw} 7.1$ Darfield and 22 February 2011 Mw 6.2 Christchurch, New Zealand, Earthquakes. Seismological Research Letters, 82(6), pp.939949.

Hazirbaba, K. and Rathje, E., 2004. A Comparison Between in Situ and Laboratory Measurements of Pore Water Pressure Generation. (1220).

Hushmand, B., Scott, R.F. and Crouse, C.B., 1988. Centrifuge liquefaction tests in a laminar box. Géotechnique, 38(2), pp.253-262.

Idriss, I.M. and Boulanger, R.W., 2008. Soil Liquefaction During Earthquakes. Earthquake Engineering Research Institute. Oakland, CA: Earthquake Engineering Research Institute.

Ishihara, K., 1985. Stability of Natural Deposits During Earthquakes. Proceedings of The Eleventh International Conference On Soil Mechanics and Foundation Engineering, San Francisco, 12-16 August 1985.

Kishida, H., 1966. Damage to Reinforced Concrete Buildings in Niigata City with Special Reference to Foundation Engineering. Soils and Foundations, 6(1), pp.71-88.

Kitagawa, Y. and Hiraishi, H., 2004. Overview of the 1995 Hyogo-Ken Nanbu Earthquake and Proposals for Earthquake Mitigation Measures. Journal of JAEEJournal of Japan Association for Earthquake Engineering, 4(3), pp.1-29.

Kiyota, T., Furuichi, H., Hidayat, R.F., Tada, N. and Nawir, H., 2020. Overview of long-distance flow-slide caused by the 2018 Sulawesi earthquake, Indonesia. Soils and Foundations, 60(3), pp.722-735.

Koseki, J., Yoshida, T. and Sato, T., 2005. Liquefaction Properties of Toyoura Sand in Cyclic Tortional Shear Tests Under Low Confining Stress. Soils and Foundations, 45(5), pp.103-113.

Kramer, S.L., 1996. Geotechnical Earthquake Engineering. Prentice-Hall International.

Kutter, B.L., Carey, T.J., Stone, N., Bonab, M.H., Manzari, M.T., Zeghal, M., Escoffier, S., Haigh, S.K., Madabhushi, G.S.P., Hung, W., Kim, D.-S., Kim, N.R., Okamura, M., Tobita, T., Ueda, K. and Zhou, Y.-G., 2020a. LEAP-UCD-2017 V. 1.01 Model Specifications. In: Model Tests and Numerical Simulations of Liquefaction and Lateral Spreading. Cham: Springer International Publishing.pp.3-29.

Kutter, B.L., Carey, T.J., Stone, N., Zheng, B.L., Gavras, A., Manzari, M.T., Zeghal, M., Abdoun, T., Korre, E., Escoffier, S., Haigh, S.K., Madabhushi, G.S.P., Madabhushi, S.S.C., Hung, W.-Y., Liao, T.-W., Kim, D.-S., Kim, S.-N., Ha, J.G., Kim, N.R., Okamura, M., Sjafruddin, A.N., Tobita, T., Ueda, K., Vargas, R., Zhou, Y.-G. and Liu, K., 2020b. LEAP-UCD-2017 Comparison of Centrifuge Test Results. In: B.L. Kutter, M.T. Manzari and M. Zeghal, eds. Model Tests and Numerical Simulations of Liquefaction and Lateral Spreading. Cham: Springer International Publishing.pp.69-103.

Maharjan, M. and Takahashi, A., 2014. Liquefaction-induced deformation of earthen embankments on non-homogeneous soil deposits under sequential ground motions. Soil Dynamics and Earthquake Engineering, 66, pp.113-124.

Manzari, M.T., Ghoraiby, M. El, Kutter, B.L., Zeghal, M., Abdoun, T., Arduino, P., Armstrong, R.J., Beaty, M., Carey, T., Chen, Y., Ghofrani, A., Gutierrez, D., Goswami, N., Haigh, S.K., Hung, W.Y., Iai, S., Kokkali, P., Lee, C.J., Madabhushi, 
S.P.G., Mejia, L., Sharp, M., Tobita, T., Ueda, K., Zhou, Y. and Ziotopoulou, K., 2018. Liquefaction experiment and analysis projects (LEAP): Summary of observations from the planning phase. Soil Dynamics and Earthquake Engineering, 113(May 2017), pp.714-743.

Manzari, M.T., Kutter, B.L., Zeghal, M., Iai, S., Tobita, T., Madabhushi, S.P.G., Haigh, S.K., Mejia, L., Gutierrez, D.A., Armstrong, R.J., Sharp, M.K., Chen, Y.M. and Zhou, Y.G., 2015. LEAP projects: Concept and challenges. Geotechnics for Catastrophic Flooding Events - Proceedings of the 4th International Conference on Geotechnical Engineering for Disaster Mitigation and Rehabilation, GEDMAR 2014, pp.109-116.

Ng, C.W.W., 2014. The state-of-the-art centrifuge modelling of geotechnical problems at HKUST. Journal of Zhejiang University: Science A, 15(1), pp.1-21.

Oka, F., Tsai, P., Kimoto, S. and Kato, R., 2012. Damage patterns of river embankments due to the 2011 off the Pacific Coast of Tohoku Earthquake and a numerical modeling of the deformation of river embankments with a clayey subsoil layer. Soils and Foundations, 52(5), pp.890-909.

Rapti, I., Lopez-Caballero, F., ModaressiFarahmand-Razavi, A., Foucault, A. and Voldoire, F., 2018. Liquefaction analysis and damage evaluation of embankment-type structures. Acta Geotechnica, 13(5), pp.10411059.

Sasaki, Y., Towhata, I., Miyamoto, K., Shirato, M., Narita, A., Sasaki, T. and Sako, S., 2012. Reconnaissance report on damage in and around river levees caused by the 2011 off the Pacific coast of Tohoku Earthquake. Soils and Foundations, 52(5), pp.1016-1032.

Schofield, A.N., 1981. Dynamic and Earthquake Geotechnical Centrifuge Modelling. Proc. of Int. Conf. on Recent Advances in Geotechnical Earthquake Engineering and Soil Dynamics, pp.1081-1100.

Scott, R.F. and Zuckerman, K.A., 1972.
Sandblows and Liquefaction. The Great Alaska Earthquake Of 1964-EngineeringPublication 1606, pp.179-189.

Sharp, M.K., Dobry, R. and Abdoun, T., 2003. Liquefaction centrifuge modeling of sands of different permeability. Journal of Geotechnical and Geoenvironmental Engineering, 129(12), pp.1083-1091.

Suzuki, W., Aoi, S., Kunugi, T., Kubo, H., Morikawa, N., Nakamura, H., Kimura, T. and Fujiwara, H., 2017. Strong motions observed by K-NET and KiK-net during the 2016 Kumamoto earthquake sequence 2016 Kumamoto earthquake sequence and its impact on earthquake science and hazard assessment Manabu Hashimoto, Martha Savage, Takuya Nishimura and Haruo Horikawa 4. . Earth, Planets and Space, 69(1).

Tabaroei, A., Abrishami, S. and Hosseininia, E.S., 2017. Comparison between two different pluviation setups of sand specimens. Journal of Materials in Civil Engineering, 29(10), pp.1-11.

Takada, N., Nishi, M. and Fukuda, M., 1996. Damage to River Levees and Revetments. Soils and Foundations, 36(Special), pp.241-254.

Tatsuoka, F., Ochi, K., Fujii, S. and Okamoto, M., 1986. Cyclic undrained triaxial and torsional shear strength of sands for different sample preparation methods. Soils and Foundations, 26(3), pp.23-41.

Towhata, I., 2008. Geotechnical Earthquake Engineering. Springer Series in Geomechanics and Geoengineering. Berlin, Heidelberg: Springer Berlin Heidelberg.

Towhata, I., Goto, S., Taguchi, Y. and Aoyama, S., 2013. Liquefaction Consequences and Learned Lessons During the $2011 \mathrm{Mw}=9$ Gigantic Earthquake. Indian Geotechnical Journal, 43(2), pp.116-126.

Towhata, I., Maruyama, S., Kasuda, K., Koseki, J. and Wakamatsu, K., 2014. Liquefaction in the Kanto region during the 2011 off the paci fi c coast of Tohoku earthquake. Soils and 
Foundations, 54(4), pp.859-873.

Yamada, S., Orense, R.P. and Cubrinovski, M., 2011. Earthquake News Geotechnical Damage due to the 2011 Christchurch, New Zealand. ISSMGE Bulletin, 5(2), pp.27-45.

Yegian, M.K., Ghahraman, V.G. and Harutiunyan, R.N., 1994. Liquefaction and
Embankment Failure Case Histories, 1988 Armenia Earthquake. Journal of Geotechnical Engineering, 120(3), pp.581-596.

Youd, T.L., 1995. Liquefaction-Induced Lateral Ground Displacement. Proceedings: Third International Conference on Recent Advances in Geotechnical Engineering and Soil Dynamics 2-7 April 1995, St. Loius, Missouri, pp.911--. 